\title{
PRIMARY SUBACUTE OSTEOMYELITIS OF THE TALUS
}

\author{
X. A. SKEVIS
}

From Saint Sophia Hospital for Sick Children, Athens

\begin{abstract}
In four children with primary subacute osteomyelitis of the talus seen one to five months from the onset of symptoms, the only constant complaints were of pain and a limp. All four were treated by curettage, immobilisation in plaster and appropriate antibiotics. All the bony cavities were healed within eight months of the operation and there were no growth disturbances nor any abnormalities of the adjacent joints.
\end{abstract}

Acute haematogenous osteomyelitis is the commonest type of bone infection in Greece, as it probably is in most other countries. Primary chronic infections of bone, except as the sequel to acute infection, are much less common. Sir Benjamin Brodie (1836) first described a localised abscess in the tibia which developed without previous acute illness and did not produce systemic signs. Garré (1893) later reported a low-grade inflammation which he called sclerosing non-suppurative osteomyelitis; and Phemister (1929) also wrote on primary chronic osteomyelitis.

Primary subacute osteomyelitis, with which this
Trueta and Morgan (1954), James (1953), King and Mayo (1969) and Mollan and Piggot (1977) contained no reported cases of osteomyelitis of the talus. White and Dennison (1952), in their review of 212 children with osteomyelitis, included only five with infection of the bones of the tarsus, and they did not state which bones were affected.

The only previous publications dealing with primary subacute osteomyelitis of the talus are by Robertson (1967) who described two examples in children aged respectively five and eight years, and by Antoniou and Conner (1974) who reported on seven cases in children

Table I. Principal clinical and laboratory details

\begin{tabular}{|c|c|c|c|c|c|c|c|}
\hline Case & Sex & $\begin{array}{l}\text { Age } \\
\text { (years) }\end{array}$ & $\begin{array}{l}\text { Time from onset of } \\
\text { symptoms to admission } \\
\text { (months) }\end{array}$ & Clinical signs on admission & $\begin{array}{l}\text { ESR } \\
(\mathbf{m m} / 1 \text { st } h r)\end{array}$ & $\begin{array}{l}\text { Leucocytes } \\
\left(\text { per } \mathrm{mm}^{3}\right)\end{array}$ & $\begin{array}{l}\text { Mantoux } \\
\text { test }\end{array}$ \\
\hline 1 & $\mathbf{M}$ & 1.5 & 3 & $\begin{array}{l}\text { Limp and moderate pain. } \\
\text { Slight swelling over anterior } \\
\text { part of lateral malleolus and } \\
\text { ankle. No fever. }\end{array}$ & 13 & 5200 & - \\
\hline 2 & $\mathbf{M}$ & 2 & 1 & $\begin{array}{l}\text { Limp and moderate pain. No } \\
\text { fever. }\end{array}$ & 5 & 5500 & - \\
\hline 3 & $\mathrm{~F}$ & 4 & 5 & $\begin{array}{l}\text { Limp and moderate pain. } \\
\text { Slight swelling over anterior } \\
\text { part of lateral malleolus. No } \\
\text { fever. }\end{array}$ & 7 & 5000 & - \\
\hline 4 & $\mathbf{M}$ & 5 & 2 & $\begin{array}{l}\text { Limp and moderate pain. } \\
\text { Slight swelling over anterior } \\
\text { part of ankle. No fever. }\end{array}$ & 15 & 7500 & - \\
\hline
\end{tabular}

article is concerned, also implies that the bone infection, as in the chronic form, develops without known previous disease (Lloyd-Roberts 1971). It appears to be a rare condition, especially in children; and involvement of the talus seems to be excessively rare. Even acute infection of the talus has seldom been described; thus the extensive series of acute and subacute osteomyelitis published by

X. A. Skevis, MD, MCh Orth, Senior Registrar

51 Stournara Street, Athens 102, Greece.

(C) 1984 British Editorial Society of Bone and Joint Surgery $0301-620 \mathrm{X} / 84 / 1012 \$ 2.00$ with ages ranging from 18 months to 11 years. The purpose of this present report is to describe four patients with this condition and to call attention to the existence of the clinical syndrome, so that the lesion may be diagnosed early and treated effectively without curettage.

\section{CLINICAL MATERIAL}

Between 1966 and 1974 four children with primary subacute osteomyelitis of the talus were seen at Saint Sophia Hospital for Sick Children, Athens. Their clinical details are shown in Table I. None of the children had 
sickle-cell disease; all were afebrile and apparently healthy. There was no history of injury. The symptoms common to all four cases were pain of moderate severity and a limp. The radiographic appearance in all four patients was characteristic although not diagnostic; there was a circumscribed and well-defined lytic lesion within the head of the talus in one patient (Fig. 1) and in the body of the talus in three (Figs 2 to 5).

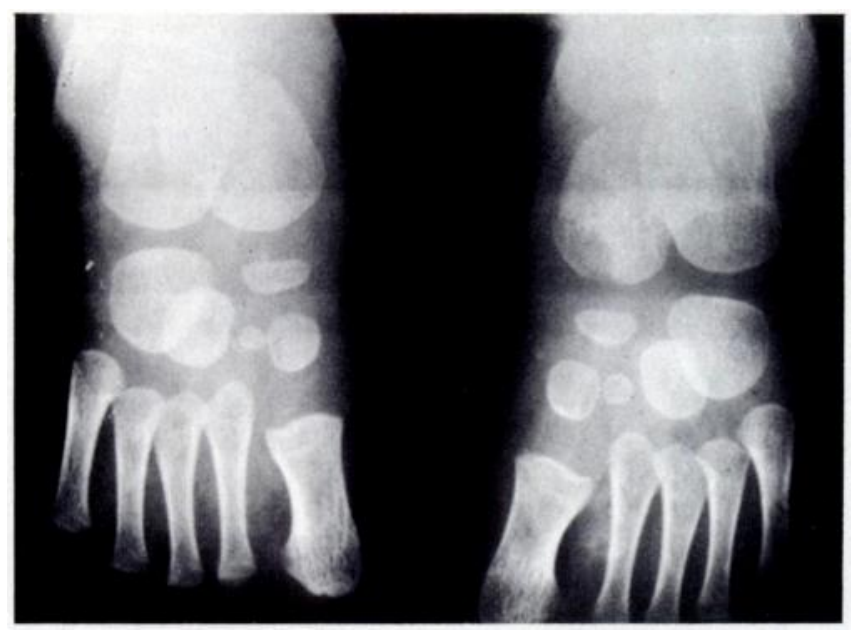

Fig. 1

Case 1. Lytic lesion in the head of the talus. ankle, showed the development of a very cellular and vascular inflammatory tissue with destruction and necrosis of the osseous tissue. The inflammatory infiltration was diffuse and consisted of lymphocytes, histiocytes and many polymorphonuclears."

All the cavities were healed within eight months of operation (Figs 7 and 8). Follow-up was for a minimum of two years and an average of three years. In none of the

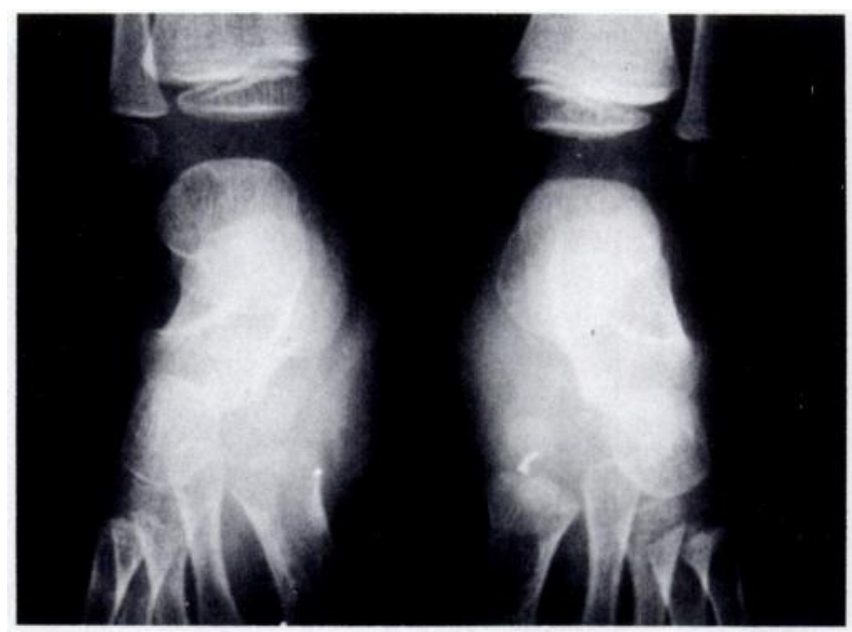

Fig. 2

Case 2. Lytic lesion in the body of the talus.

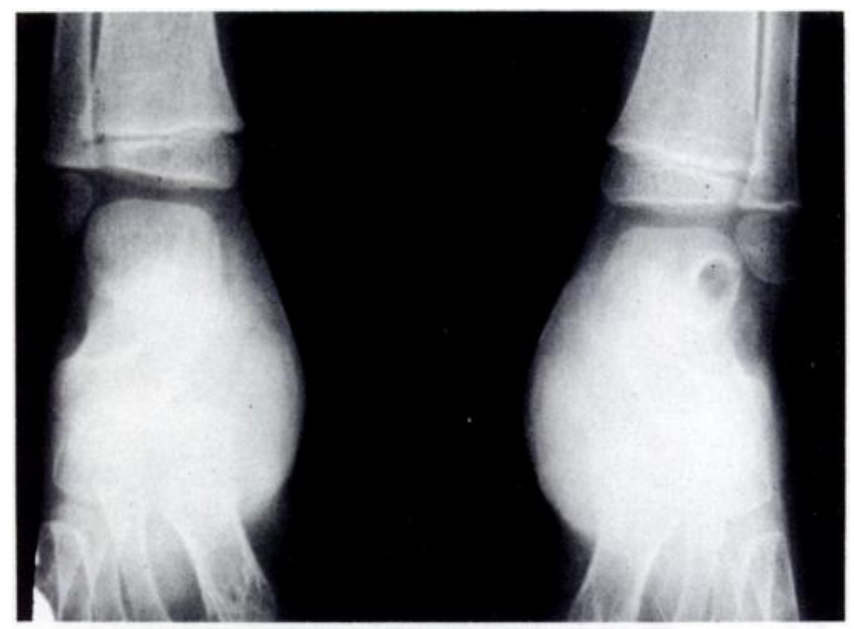

Fig. 3

Case 3. Well-defined cavity in the body of the talus.

\section{PROGRESS}

All the children were operated upon. No pus was found in any of the cavities, but granulation tissue was encountered in every instance. The lesions were curetted; they were sterile on routine culture, anaerobic culture and on culture for tuberculous and fungal organisms. In every case the curetted tissue was also sent for histological examination and was found to have the characteristic appearance of osteomyelitis (Fig. 6). The pathologist's report on Case 4 is typical and reads as follows: "Microscopy of the fragments sent, taken from round the four cases did symptoms recur.

\section{SUMMARY}

Four cases of primary subacute osteomyelitis of the talus have been reported. The condition is rare, but is a definite clinical syndrome which may pose a diagnostic problem because of the absence of clinical and laboratory signs of bone infection.

It is probable that, in all four cases, if the diagnosis had been made at the onset of the disease and effective treatment (with antibiotics and immobilisation) applied, 


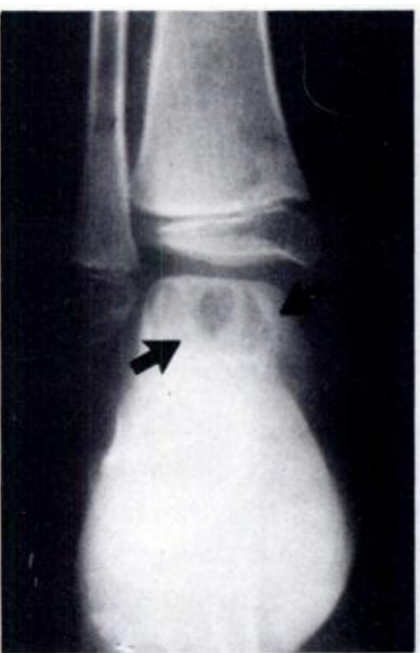

Fig. 4

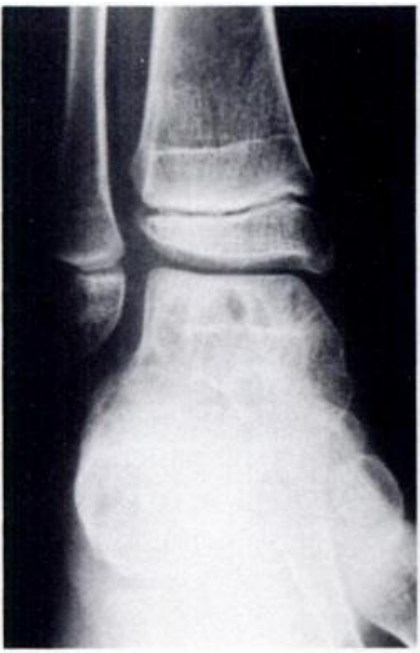

Fig. 7

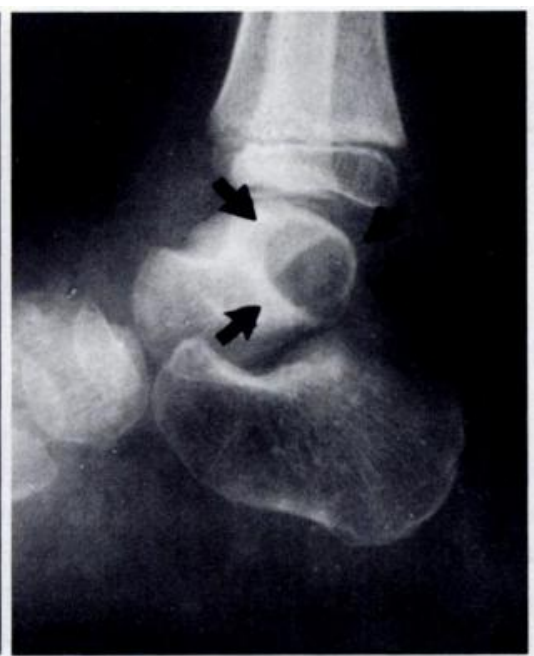

Fig. 5

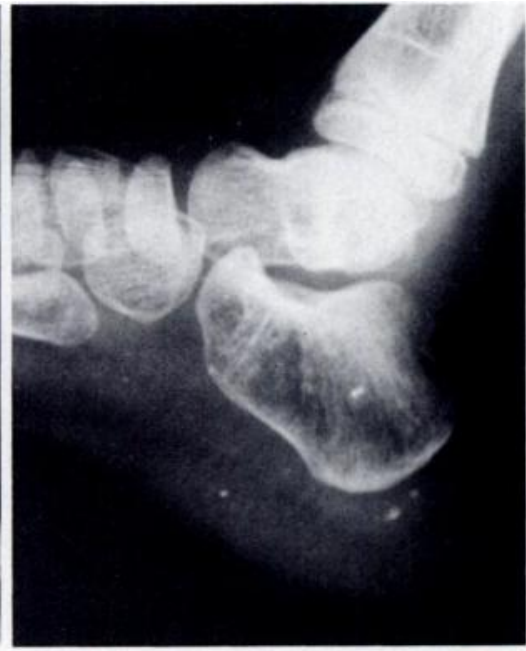

Fig. 8

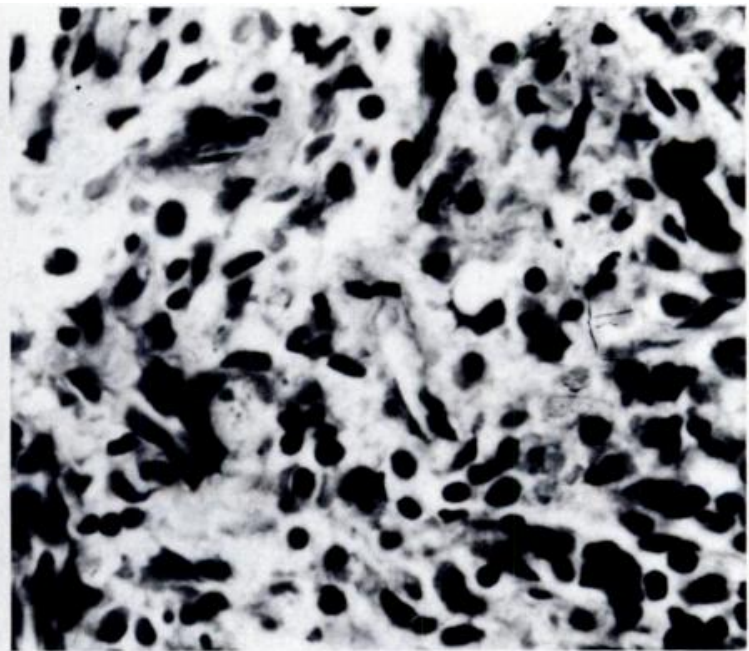

Fig. 6

Case 4. Figure 4-Large circumscribed cavity in the body of the talus. Figure 5-Lateral view. Figure 6-The bony tissue has been destroyed. The inflammatory tissue contains polymorphonuclear cells, lymphocytes, histiocytes and some plasmacytes. Figures 7 and 8-At six months from operation the extensive cavity in the head of the talus is healing.

the lytic lesions in the talus would not have developed.

When patients are seen late, as in our series, curettage is advisable, both for diagnosis and treatment.
This should be followed by an average of three months immobilisation in plaster with appropriate antibiotics for at least six months.

I am most grateful to Mr G. C. Lloyd-Roberts for his encouragement and helpful advice in the preparation of this paper.

\section{REFERENCES}

Antoniou D, Conner AN. Osteomyelitis of the calcaneus and talus. J Bone Joint Surg [Am] 1974;56-A:338-45.

Brodie BC. Pathological and surgical observations on diseases of the joints. 4th ed. London: Longman, Rees, Orme, Brown, Green and Longman, 1836.

Garré C. Ueber besondere Formen und Folgezustände der akuten infektiösen Osteomyelitis. Beitr z Klin Chir, Tübing, 1893;10:241-98.

James T. Acute osteomyelitis in infancy and early childhood. Br J Surg 1953;41:87-91.

King DM, Mayo KM. Subacute haematogenous osteomyelitis. J Bone Joint Surg [Br] 1969;51-B:458-63.

Lloyd-Roberts GC. Orthopaedics in infancy and childhood. London: Butterworths, 1971.

Mollan RAB, Piggot J. Acute osteomyelitis in children. J Bone Joint Surg [ Br] 1977;59-B: 2-7.

Phemister DB. Chronic fibrous osteomyelitis. Ann Surg 1929;90:756-64.

Robertson DE. Primary acute and subacute localized osteomyelitis and osteochondritis in children. Canad J Surg 1967;10:408-13.

Trueta J, Morgan JD. Late results in the treatment of 100 cases of acute haematogenous osteomyelitis. Br J Surg 1954;41:449-57.

White M, Dennison WM. Acute haematogenous osteitis in childhood: a review of 212 cases. J Bone Joint Surg [Br] 1952;34-B:608-23. 